\title{
EFFECT OF NANO DICALCIUM PHOSPHATE SUPPLEMETATION ON EGGSHELL STRUCTURE AND CALCIUM AND PHOSPHORUS UTILIZATION
}

\author{
T. M. El-Sheikh ${ }^{1}$ and Manal K. Abou-Elnaga ${ }^{2}$ \\ ${ }^{1}$ Poultry Production Department, Faculty of Agriculture, Sohag University,Sohag, Egypt. \\ talatm2@ayahoo.com \\ ${ }^{2}$ Poultry and Fish Production Department, Faculty of agriculture, Menoufyia University \\ Shebin El-Kom, Shebin El-Kom, Egypt. Manal.abouelnaga2@agr.menofia.edu.eg,
} manalkamal16@yahoo.com

(Received 13/11/2018, accepted 25/12/2018)

\section{SUMMARY}

$\mathrm{T}$

This study was conducted to evaluate the efficiency of dietary varying levels of nano di-calcium phosphate (NDCP) on eggshell quality [total thickness (EST), mammillary layer thickness (MT), and mammillary density (MD)] egg mineral contents, bone breaking strength, serum calcium and phosphorus concentrations and calcium $(\mathrm{Ca})$ and phosphorus $(\mathrm{P})$ retention in old laying hen. Therefore, one hundred and eighty brown LSL hens at the age of 52 weeks of age were used for 12 weeks at the end of their production period. Hens were divided into four equal groups, 45 birds/group with nine replicates each. The treatments were as follows: Group (1): basal diet (control); Group (2): basal diet + 200g NDCP/ ton; Group (3): basal diet + 400g NDCP/ ton; and Group (4): basal diet + 800g NDCP/ ton. Results detected that serum $\mathrm{Ca}$ and $\mathrm{P}$ concentration, tibia fresh weight, tibia ash, tibia $\mathrm{Ca}, \mathrm{Ca}$ and $\mathrm{P}$ retention were significantly increased stuck with the increase in NDCP supplementation level up to $400 \mathrm{~g} /$ ton and tend to decrease after that. Furthermore, Yolk mineral content ( $\mathrm{Ca}$ and $\mathrm{p}$ ) accumulation was significantly decreased with increasing NDCP levels. There were no significant differences in tibia breaking strength and tibia $\mathrm{P}$ with the supplementation in comparison with the control group. Eggshell thickness and breaking strength increased parallel to the increase in NDCP levels due to the increase in palisade layer and mammillary layer. In conclusion supplementation of NDCP up to $400 \mathrm{~g} /$ ton to layers diet may be help in solving the problems of egg shell weakness at the end of egg laying season or old hen production.

Keywords: nano-dicalcium phosphate, old laying hens, egg shell criteria, Ca and P, mineral retention.

\section{INTRODUCTION}

Between 10 and $15 \%$ of laying eggs are lost before and during the collection process due to problems in the shell quality (Coutts et al., 2007). Therefore, different strategies, especially mineral nutrition and supplementation, have been considered to improve eggshell quality (Nys, 2004). Most mineral sources used in diets for laying hens are derived from inorganic compounds such as oxides, sulfates, carbonates, and phosphates. However, organic mineral sources have emerged on the market with the prospect of being more easily absorbed and retained by birds, thereby reducing the excretion of trace minerals that potentially pollute the environment (Zamani et al., 2005).

A considerable percent of all eggs is ruined due to cracked eggshells as shell quality declines with age during the laying period. This is a concern for food safety as well as an economical problem. Parallel with reduced shell quality the bone strength declines to an extent that the animal's welfare is threatened. Laying hens of Lohman Selected Leghorn (LSL) and Lohman Brown (LB) were monitored during a complete production period. The first sign of declining shell quality was found in mid-production in both hybrids, and even before, in peak production, decreasing bone strength was detected (Wistedt, 2013).

Calcium $(\mathrm{Ca})$ and phosphorous $(\mathrm{P})$ are required in large quantities by poultry and involved in many biological processes (Hassan et al., 2016). Calcium requirement is easily satisfied with low price sources such as limestone or oyster shell (Williams et al., 2000). 
Jonchere et al. (2012) Calcium is necessary for eggshell formation which is absorbed from the intestine. Additionally, a part of the absorbed Ca from intestine is stored in medullar bone, which is later released for the calcification of eggshell. Therefore, the maintenance of bone health is important for the protection of hens' health and optimizing eggshell quality.

Egg shell quality is a vital factor for the industry, and calcium is the primary element influencing this (Lavelin et al., 2000). In general, the smaller the particles, the higher and more effective their absorption, especially if the particle size is below $100 \mathrm{~nm}$ (Hett, 2004).

Recently, nanotechnology plays a major role in the areas of research in poultry science. The future challenges of the poultry science research include improving the feed efficiency, controlling the macro and micro nutrient absorption, tackling the decreases targeting drug delivery, safely growth promoter, modifying the contents of the egg like full protein egg and cholesterol free egg, reducing the energy and protein wastage in unproductive physiological purposes. Thereby, improving the feed efficiency and reducing the price of the poultry meat; it can be achieved through the application of Nano biotechnology and Nano immunology to poultry research (Kannaki and Verma, 2006). In the recent years, application of nanotechnology as a noble strategy increasing the bioavailability of minerals particularly calcium by enhancing its surface area which could result in an increase in its absorption and utilization (Vijayakumar and Balakrishnan, 2014). Mineral nanoparticles may be helpful in reducing the excretion of unutilized minerals, thereby minimizing the environmental pollution especially in large scale poultry farming (Tiwari, 2015).

The nanoparticles, which is at least one dimension reduced to a Nano metric size, exhibits new electrical, magnetic, mechanical and biological properties (Gref et al., 1994) which have been determined as critical factors influencing particle uptake (Delie,1998). Therefore, the new phenomena and properties of nanoparticles may have unique potential application (Sirirat et al., 2013).

Research shows that due to small size and unique physical properties of nanoparticles, these feed additives could have better bioavailability and interaction with other feed components (Sahoo et al., 2014).

The supplement of calcium and phosphorus in the form of nanoparticles is considered as strategy to bring down the cost of calcium and phosphorus supplement and the feed (Vijayakumar and Balakrishnan, 2014).

Hence, such a nanoparticles based strategy needs to be explored. However, nano particles behaves differently from coarse particles and therefore its usage as mineral supplement is viewed skeptically. Hence it is imperative to verify its safety on biological medium (Vijayakumar and Balakrishnan, 2015).

Therefore, with this background, this investigation was focused on reducing the inclusion levels of calcium and phosphorus sources and increasing the absorption of minerals by reducing their particle size in Nano forms and study the effect of nano di calcium phosphate (NDCP) supplementation on mineral utilization and bone mineralization of brown LSL laying hens.

\section{MATERIALS AND METHODS}

\section{Experiment location:}

The present study was conducted at the Poultry Research Farm and the Poultry Nutrition Laboratory, Faculty of Agriculture, Menoufia University, Shebin El-Kom, Egypt during June 2017 to August 2017.

\section{Animals and experimental diets:}

One hundred and eighty brown LSL hen at the age of 52 weeks of age for 12 weeks at the end of the production period. Hens were divided into four equal groups, 45 birds/ group with nine replicates each. Birds were housed in furnished layer cages. The diet was formulated according to NRC (1994) recommendations as shown in (Table 1).

The treatments of the present study were as follows: Group (1): basal diet (control); Group (2): basal diet + 200g NDCP/ ton; Group (3): basal diet + 400g NDCP/ ton; and Group (4): basal diet + 800g NDCP/ ton. 


\section{Collection and analysis samples of calcium and phosphorus retention:}

At 63 weeks of age, a balance trial was conducted to determine calcium and phosphorus retention. Nine hens were randomly chosen from each dietary treatment, transferred to collective metabolic cages and fed the experimental diets supplemented with $\mathrm{Cr}_{2} \mathrm{O}_{3}(0.2 \%)$ for a preliminary period of three days for adaptation of hens to experimental conditions, followed by a three-days collection period. Excreta were oven dried at $70 \mathrm{C}^{\circ}$ for 24 hours, then ground. Diets and excreta samples were analyzed for $\mathrm{Ca}$ and $\mathrm{P}$ according to the official methods of AOAC (2003).

Table (1): Composition and chemical analysis of the experimental laying basal diets.

\begin{tabular}{lcc}
\hline Ingredient & Control \\
\hline Ground yellow corn $(8.5 \% \mathrm{CP})$ & $\mathrm{gg}$ & 63.80 \\
Ground yellow corn $(8.5 \%)$ & & 25.71 \\
Soy bean meal $(44 \% \mathrm{CP})$ & & 0.80 \\
Corn gluten $(60 \%)$ & 7.00 \\
Limestone, ground & 2.00 \\
Di-calcium phosphate & 0.3 \\
Vitamin and mineral mixture & 0.30 \\
Salt (Sodium chloride) & 0.09 \\
DL-methionine & 100.00 \\
Total & \\
Calculated value & \\
Crude protein, $\%$ & 17.23 \\
ME, Kcal/kg diet & 2711 \\
C/P ratio & 157.34 \\
Lysine, $\%$ & 0.89 \\
Methionine, $\%$ & 0.38 \\
Calcium, $\%$ & 3.18 \\
Available phosphorus, $\%$ & 0.48 \\
\hline
\end{tabular}

${ }^{1}$ Vitamin and Mineral mixture at 0.30\%of the diet supplies the following per kilogram of the diet: Vit. A, 12000 IU; Vit.D3, 2500 IU; Vit. E, $10 \mathrm{mg}$; Vit.K3, 3mg; Vit.B1, $1 \mathrm{mg}$; Vit.B2, 4mg; pantothenic acid, $10 \mathrm{mg}$; Nicotinic acid, 20 mg; Folic acid, $1 \mathrm{mg}$; Biotin, $0.05 \mathrm{mg}$; Niacin , $40 \mathrm{mg}$; Vit.B6, $3 \mathrm{mg}$, Vit. B12, $20 \mathrm{mcg}$; Chaline Chloride, $400 \mathrm{mg}$; Mn, $62 \mathrm{mg}$; $\mathrm{Fe}, 44 \mathrm{mg} ; \mathrm{Zn}, 56 \mathrm{mg} ; \mathrm{I}, 1 \mathrm{mg} ; \mathrm{Cu}, 5 \mathrm{mg}$ and Se, $0.01 \mathrm{mg}$.

${ }^{2}$ Dl-Methionine: $98 \%$ feed grade (contains $98 \%$ Methionine)

${ }^{3}$ Calculate according to NRC (1994).

Apparent $\mathrm{Ca}$ and $\mathrm{P}$ retention of each dietary treatment was calculated according to Shirley and Edwards, (2003) equations:

$$
\text { Ca or P retention } \%=100-\left\{\left(100 \times \frac{\% \mathrm{Cr}_{2} \mathrm{O}_{3} \text { feed }}{\% \mathrm{Cr}_{2} \mathrm{O}_{3} \text { excreta }}\right) \times\left(\frac{\% \text { element excreta }}{\% \text { element feed }}\right)\right\}
$$

At the end of the balance trial, blood samples were collected in sterile un-heparinized tubes and centrifuged at $3000 \mathrm{rpm}$ for $15 \mathrm{~min}$, and stored frozen at $-20 \mathrm{C}^{\circ}$ until the determination of $\mathrm{Ca}$ and $\mathrm{P}$.

\section{Collection and analysis of samples Egg shell quality:}

Representative egg samples (10 eggs) from each treatment were collected monthly throughout the experimental period in order to determine egg and shell quality. Eggs at the final period (at the age of 64 wks.) were also used for egg yolk and shell mineral content analysis. Samples of eggshell were randomly taken to investigate ultra-structural variations. The specimens were prepared by cutting a piece $\left(1 \mathrm{~cm}^{2}\right) \mathrm{of}^{2}$ shell from the equatorial region of each egg. The shell membranes were carefully removed by first soaking in water. The loosely adhering membranes were then gently peeled from the edge of the sample inwards. To remove the remaining tightly bound membrane fiber, each sample was then immersed overnight in 6\% sodium hypochlorite, $4.12 \%$ sodium chloride and $0.15 \%$ sodium hydroxide. Afterward, the shells were washed in water and dried at room temperature for at least $48 \mathrm{~h}$ according to the methodology described by Radwan et al. (2010). 
Following these preparative treatments, two samples from each egg were mounted in inner side uppermost and in vertically manner on aluminum stubs, coated with gold for $3 \mathrm{~min}$. in an Emscope Sputter Coater. These samples were examined using JEOL JSM-T330A scanning electron microscopy at $15 \mathrm{Kv}$. After gold coating, the specimens were observed in the scanning electron microscope and photographed at various magnifications ranging from $75 \mathrm{X}$ to $500 \mathrm{X}$. Total shell thickness, mammillary layer thickness, palisade layer thickness and cuticle layer were measured from the resulting photographs. For the analysis of the cross-section of the shell, the variables measured were the palisade layer thickness $(\mu \mathrm{m})$, the mammillary button thickness, and the total thickness (palisade + mammillary). The percentage of the palisade layer thickness and the percentage of the mammillary button thickness were obtained by calculating the ratio of the thickness of each layer to the total thickness measure.

The incidence of ultra-structure variants at the level of the layers was assessed according to the methodology and terminology at the central Lab -Scanning electron microscope unit - Faculty of Agriculture- Ain Shams University.

\section{Collection and analysis of diet samples and excreta content of $\mathrm{Ca}$ and $\mathrm{P}$ :}

Crude protein, calcium and phosphorus contents of the diet samples were determined by the standard Kjeldahl method and atomic absorption spectro-photometer methods, respectively (AOAC, 2003). Dry matter of diet samples was determined by drying at $135 \mathrm{C}^{\circ}$ for $3 \mathrm{~h}$. The metabolizable energy was calculated according to NRC (1994) from the proximate composition of the diet.

\section{Collection and analysis of Bone breaking strength samples:}

Bone breaking strength (force necessary to break bone) was tested using materials testing machines (Tinnitus Olsen, force measuring system, H5KS, capacity $5 \mathrm{KN}, 510 \mathrm{kgf}, 1,125 \mathrm{ibf}$, over $2.5 \mathrm{KN}$ ), Faculty of Agriculture- Ain Shams University. Tibia was dissected and air-dried for 7 days, fat extracted and as heed at $600 \mathrm{C}^{\circ}$ for $6 \mathrm{~h}$. A known tibia ash samples were subjected to wet digestion utilizing (AOAC, 2003) for the determination of $\mathrm{Ca}$ and $\mathrm{P}$ bone mineral contents according to the methods of Allen et al., (1997).

\section{Statistical analysis:}

Data were statistically analyzed by the completely randomized design using SPSS (2011) program and the differences among means were determined using Duncan's multiple range test (Duncan 1955). Percentages were transformed to the corresponding arcsine values before performing statistical analysis according to the following model: -

$$
\mathrm{Y}_{\mathrm{ij}}=\mu+\alpha_{\mathrm{i}}+\mathrm{E}_{\mathrm{ij}}
$$

Where; Yij = an observation; $\mu=$ overall mean; $\alpha_{i}=$ effect of treatment $(i=1,2, \ldots 5)$, and $\mathrm{e}_{\mathrm{ij}}=$ random error.

\section{RESULTD AND DISCUSSION}

\section{Serum calcium and phosphorus concentrations:}

Effects of different levels of NDCP supplementation on serum calcium and phosphorus concentrations are given in Table (2). Results detected that $\mathrm{Ca}$ and $\mathrm{P}$ concentrations were significantly increased with the increasing level of NDCP supplementation, They were 11.46 and 11.93 for $\mathrm{Ca}$, the corresponding values were 6.36 and 7.33 for $\mathrm{P}$ at 200 and $400 \mathrm{~g} /$ ton, respectively compared to the control group; being $10.6 \mathrm{Ca}$ and 5.31 P. The increasing of serum $\mathrm{Ca}$ and $\mathrm{P}$ stuck with the increase in NDCP supplementation level up to $400 \mathrm{~g} / \mathrm{ton}$ and tend to decrease after that $(9.79$ and 6 for $800 \mathrm{~g} / \mathrm{ton})$.

Ganjigohari et al. (2018) noted that concentration of calcium in plasma is in two forms; connected to other compounds or ionic and they noted that there was no evidence regarding the effect of $\mathrm{CaCo}_{3}$ nano particles on blood calcium content of laying hens. The amount of serum protein is an important factor affecting the first form of plasma calcium concentration (Lesson and Summers, 1969).

Vijayakumar and Balakrishnan (2014) found that serum mineral profile did not show any significant differences due to interventions made which again reinforces the recommendation of reducing the level of $\mathrm{P}$ supplementation to $50 \%$ by calcium phosphorus nanoparticles as the bird were healthy. 
Table (2): Effect of dietary nano di-calcium phosphate (NDCP) supplementation on serum and yolk calcium and phosphorus contents.

\begin{tabular}{|c|c|c|c|c|}
\hline \multirow{2}{*}{ Treatment $^{1}$} & Serum $\mathrm{Ca}$ & Serum P & Egg Yolk Ca & Egg Yolk P \\
\hline & \multicolumn{2}{|c|}{----------mg/ dl--------- } & - & \\
\hline Control, $\mathrm{T}_{1}$ & $10.60^{\mathrm{c}} \pm 0.14$ & $5.31^{\mathrm{d}} \pm 0.27$ & $13.118^{\mathrm{a}} \pm 0.58$ & $5.62^{2,3, \mathrm{a}} \pm 0.2$ \\
\hline $\mathrm{T}_{2}, 200 \mathrm{~g} /$ ton & $11.46^{\mathrm{b}} \pm 0.57$ & $6.36^{\mathrm{b}} \pm 0.11$ & $13.86^{\mathrm{a}} \pm 0.27$ & $5.51^{\mathrm{b}} \pm 0.12$ \\
\hline $\mathrm{T}_{3}, 400 \mathrm{~g} /$ ton & $11.93^{\mathrm{a}} \pm 0.24$ & $7.33^{\mathrm{a}} \pm 0.27$ & $12.14^{\mathrm{b}} \pm 0.71$ & $4.15^{\mathrm{c}} \pm 0.18$ \\
\hline $\mathrm{T}_{4}, 800 \mathrm{~g} /$ ton & $9.79^{\mathrm{d}} \pm 0.077$ & $6.01^{c} \pm 0.24$ & $11.16^{\mathrm{ac}} \pm 0.50$ & $3.77^{\mathrm{d}} \pm 0.11$ \\
\hline Sig & * & * & * & $*$ \\
\hline
\end{tabular}

Berne and Levy (1998) noted that during formation of eggshell in the laying hen uterus, the circulation rate of plasma calcium is very fast and its concentration decreases rabidly, which causes reabsorption of calcium from bones to increase the plasma calcium concentration again (Pelica et al. (2011) suggested that increasing the amount of calcium (3.7\%) in the diet lead to an increment in blood calcium in laying hens. Sirirat et al. (2013) reported that addition of nano - chromium picolinate to laying hens diets at levels of 500 or 3000ppb had no significant effect on Ca retention.

Gross et al. (2014) reported that calcium phosphate materials in nano- size have higher specific surface area and surface roughness compared to conventional calcium phosphate materials. Therefore, nano-sized calcium phosphate materials have stronger interaction with organic materials.

Rajendran (2013) reported that calcium phosphate materials in nano-size are expected to have better bioactivity compared to conventional materials since supplementation of mineral in the form of nano increases bioavailability and efficiency of utilization by increasing the surface area.

\section{Egg mineral accumulation in laying hens:}

Results in Table (2) show that yolk mineral content ( $\mathrm{Ca}$ and $\mathrm{p}$ ) accumulation was significantly decreased with increasing nano di calcium phosphate (NDCP) levels. The highest levels of $\mathrm{Ca}$ and $\mathrm{P}$ was obtained in hens fed the control diet (13.18 and $5.62 \mathrm{mg}$ ), respectively compared to the other treatments.

\section{Tibia biochemical parameters:}

The biochemical parameters and mineralization of tibia of laying hens with different levels of Nano dicalcium phosphate supplementation are presented in Table (3). Data illustrated significantly higher tibia fresh weight $(28.98,28.69,29.32 \mathrm{~g})$; tibia ash $(5.10,5.03,5.23 \mathrm{~g})$ and tibia calcium $(10.46,12.27,10.46 \mathrm{mg})$ with different levels of supplementation compared to $25.06 \mathrm{~g}, 4.40$ and $10 \mathrm{mg}$, respectively with the above parameters in the control group. Furthermore, no significant differences were noticed in all groups in tibia breaking strength and tibia $\mathrm{P}$ with the supplementation in comparison with the control group.

On the other hand, Ganjigohari et al. (2018) found that treatments (replacing 50\% of the calcium carbonate; $\mathrm{CaCo}_{3}$ in the diet by Nano calcium carbonate had no effect on tibia ash. However, there are no documents in the literature regarding the effect of $\mathrm{CaCo}_{3}$ nanoparticles on tibia thickness of laying hens. Vijayakumar and Balakrishnan (2014) found that supplementation of calcium phosphate Nano-particles at varying levels did not affect the tibia bone ash content. Data on $\mathrm{Ca}, \mathrm{P}, \mathrm{K}, \mathrm{Zn}, \mathrm{Cu}, \mathrm{Fe}$ and $\mathrm{Mg}$ contents as influenced by various levels of calcium phosphate nano- particles revealed that there was no significant $(\mathrm{P} \leq$ 0.05 ) difference among the various treatments in tibia bone mineral contents. Sahoo et al. (2014) noted that inclusion of different levels of nano zinc had no effect on broilers tibia bone weight or tibia ash. Sirirat et al. (2013) noted that retention of $\mathrm{Cu}, \mathrm{Fe}, \mathrm{Ca}$ and $\mathrm{P}$ show no difference when the chickens were fed diets containing $500 \mathrm{ppb}$ and $3000 \mathrm{ppb}$ nano $\mathrm{Cr}$ pic.

\section{Calcium and Phosphorus excretion and retention:}

Data presented in Table (4) show calcium and phosphorus retention in hens fed different levels of Nano di - calcium phosphate supplementation. Data revealed that $\mathrm{Ca}$ and $\mathrm{P}$ retention increased with increasing dietary levels of Nano di calcium phosphate up to $400 \mathrm{~g} /$ ton, but minerals retention in hens fed over dosage of NDCP were equal to or less than the control. These results indicated that the addition of NDCP improved the absorption of $\mathrm{Ca}$ and $\mathrm{P}$ and subsequent reduction in $\mathrm{Ca}$ excretion, while $\mathrm{P}$ excretion was not significant. 
Table (3): Effect of dietary nano di-calcium phosphate (NDCP) supplementation on tibia biochemical parameters.

\begin{tabular}{|c|c|c|c|c|c|c|c|}
\hline \multirow{3}{*}{ Treatment } & \multicolumn{6}{|c|}{ Tibia parameter } & \multirow[b]{2}{*}{$P L$} \\
\hline & $\begin{array}{l}\text { Breaking } \\
\text { strength }\end{array}$ & weight, & ash & $\mathrm{Ca}$ & $\mathrm{P}$ & EST & \\
\hline & $\mathrm{kg} \mathrm{f}$ & \multicolumn{2}{|c|}{----------g--------- } & \multicolumn{2}{|c|}{---------mg------ } & & $\%$ \\
\hline Control, $\mathrm{T}_{1}$ & $3.74 \pm 0.02$ & $25.06^{\mathrm{d}} \pm 0.01$ & $4.40^{\mathrm{b}} \pm 0.17$ & $\begin{array}{l}10.00^{2,3, \mathrm{~b}} \pm \\
0.58\end{array}$ & $5.74 \pm 0.01$ & $\begin{array}{l}332.3^{2,3, \mathrm{~b}} \pm \\
3.3\end{array}$ & 78.24 \\
\hline $\mathrm{T}_{2,}, 200 \mathrm{~g} /$ ton & $4.59 \pm 0.10$ & $28.98^{\mathrm{b}} \pm 0.05$ & $5.10^{\mathrm{b}} \pm 0.62$ & $10.46^{\mathrm{b}} \pm 0.32$ & $5.86 \pm 0.04$ & $369.7^{\mathrm{a}} \pm 3.7$ & 79.80 \\
\hline $\mathrm{T}_{3,400 \mathrm{~g} / \text { ton }}$ & $3.82 \pm 0.12$ & $28.69^{c} \pm 0.03$ & $5.03^{\mathrm{b}} \pm 0.14$ & $12.27^{\mathrm{a}} \pm 0.92$ & $5.66 \pm 0.06$ & $358.3^{\mathrm{a}} \pm 3.3$ & 75.44 \\
\hline $\mathrm{T}_{4}, 800 \mathrm{~g} /$ ton & $3.95 \pm 0.05$ & $29.32^{\mathrm{a}} \pm 0.06$ & $5.23^{\mathrm{a}} \pm 0.21$ & $10.46^{\mathrm{b}} \pm 0.57$ & $5.74 \pm 0.1$ & $340.7^{\mathrm{b}} \pm 7.1$ & 76.12 \\
\hline Sig & NS & $*$ & $*$ & $*$ & NS & $*$ & NS \\
\hline
\end{tabular}

Table (4): Effect of dietary nano di-calcium phosphate (NDCP) supplementation on calcium and phosphorus excretion and retention.

\begin{tabular}{lcccc}
\hline \multirow{2}{*}{ Treatments } & \multicolumn{2}{c}{ Excreta minerals, mg } & \multicolumn{2}{c}{ Mineral retention ratio, $\%$} \\
\cline { 2 - 5 } & $\mathrm{Ca}$ & $\mathrm{P}$ & $\mathrm{Ca}$ & $\mathrm{P}$ \\
\hline Control, $\mathrm{T}_{1}$ & $12.50^{\mathrm{a}} \pm 0.57$ & $5.17 \pm 0.35$ & $39.96^{\mathrm{c}} \pm 1.20$ & $45.95^{2,3, \mathrm{~b}} \pm 0.11$ \\
$\mathrm{~T}_{2,200 \mathrm{~g} / \text { ton }}$ & $10.23^{\mathrm{b}} \pm 0.60$ & $5.55 \pm 1.10$ & $47.36^{\mathrm{b}} \pm 0.95$ & $47.14^{\mathrm{b}} \pm 0.57$ \\
$\mathrm{~T}_{3,400 \mathrm{~g} / \text { ton }}$ & $10.46^{\mathrm{b}} \pm 0.35$ & $5.40 \pm 0.70$ & $62.75^{\mathrm{a}} \pm 1.70$ & $55.84^{\mathrm{a}} \pm 0.24$ \\
$\mathrm{~T}_{4}, 800 \mathrm{~g} /$ ton & $13.18^{\mathrm{a}} \pm 0.77$ & $5.70 \pm 0.22$ & $30.09^{\mathrm{d}} \pm 0.86$ & $46.58^{\mathrm{d}} \pm 0.77$ \\
\hline Sig & $*$ & NS & $*$ & $*$
\end{tabular}

${ }^{I} T_{1}$; control, $T_{2}$; control $+200 \mathrm{~g} \mathrm{NDCP/Ton,} T_{3}$; control $+400 \mathrm{~g} \mathrm{NDCP/Ton,} T_{4}$; control $+800 \mathrm{~g} \mathrm{NDCP} / \mathrm{Ton}$.

${ }^{2}$ means \pm S.E. of 3 replicates / treatment.

${ }^{3} a, b, c . . . . . . . e t c:$ Means within the same column with different superscripts are significantly different $(P<0.05)$.

Ca $=$ Calcium. $P=$ Phosphorus.

The results pertaining to values of minerals in the tibia are in agreement with those of Hassan et al. (2016) who noted that feeding broiler chicks diets containing $0.44 \%$ of NDCP decreased the excreted Ca and $\mathrm{P}$ by about 51 and $46 \%$, respectively comparing to the control diet.

Swain et al. (2015) reported that Nano minerals are having a great potential even at very lower doses than the conventional organic and inorganic sources. Nano form of minerals supplementation increases the surface area which possibly could increase absorption and utilization leading to reduction in the quantity of supplements and ultimately reduction in mineral excretion.

\section{Effect of NDCP on eggshell ultra-structure by scanning electron microscope:}

The ultra-structure of eggshell is presented in Tables (5) and Figures (1, 2, 3 and 4). Measurements of the relative thicknesses of the mammillary layer versus the palisade layer (Table 5) indicated significant differences in the thickness of the mammillary layer and the thickness of the palisade layer in the eggs of different breaking strengths. It could be demonstrated that the eggshell is comprised of three morphologically distinct calcified layers (The mammillary, palisade and cuticle layers). The mammillary and palisade layers comprise at least $85 \%$ of the total cross-sectional length of the eggshell (the palisade layer is about two - third of the total shell thickness). Our results revealed that the palisade layer increased as shell thickness (EST) increased according to the increase in NDCP supplementation regardless of the hen age (Fig. 4) and this means that using NDCP as diets supplementation will affect the eggshell strength, and improving the quality of the eggshell produced. 
Also, photomicrographs (Figures 1, 2, 3 and 4) revealed that the main factor affecting the shell strength is the thickness and concentration of the palisade layer around the crystals of the mammillary layer.

Table (5): Effect of nano di calcium and phosphorus supplementation on eggshell histology parameters.

\begin{tabular}{|c|c|c|c|c|c|c|c|}
\hline Treatment & EST & palisade layer & $\%$ & M LT & $\%$ & Cuticle layer & $\%$ \\
\hline Control & $332.3^{b} \pm 3.3$ & $3 \quad 260.76^{\mathrm{b}} \pm 4.1$ & 78.24 & $59.90^{\mathrm{b}} \pm 2.4$ & 18.05 & $19.87^{\mathrm{C}} \pm 1.9$ & 5.98 \\
\hline $200 \mathrm{~g} /$ ton & $369.7^{\mathrm{a}} \pm 3.7$ & $295.00^{\mathrm{a}} \pm 4.9$ & 79.80 & $57.30^{\mathrm{b}} \pm 5.1$ & 15.56 & $22.03^{\mathrm{B}} \pm 4.3$ & 5.96 \\
\hline $400 \mathrm{~g} /$ ton & $358.3^{\mathrm{a}} \pm 3.3$ & $270.33^{\mathrm{B}} \pm 9.2$ & 75.44 & $63.90^{\mathrm{b}} \pm 1.4$ & 17.83 & $26.77^{\mathrm{a}} \pm 1.2$ & 7.47 \\
\hline $800 \mathrm{~g} /$ ton & $340.7^{b} \pm 7.1$ & $259.33^{\mathrm{b}} \pm 7.0$ & 76.12 & $77.90^{\mathrm{a}} \pm 3.8$ & 22.89 & $21.23^{\mathrm{b}} \pm 1.9$ & 6.23 \\
\hline Sig & $*$ & $*$ & & $*$ & & $*$ & \\
\hline
\end{tabular}

Nascimento et al. (1992) noted that all eggshell layers were significantly reduced as the age of breeder and increased erosion of the calcium reserve assembly region of the mammillary layer as the breeder hen ages could potentate separation of the mammillary layer and shell membranes. Increasing the palisade layer thickness of eggshells is important; therefore it is likely that alterations in the thickness of the palisade layer, independent of structural reorganization of the palisade columns, could affect shell strength, as the study of Radwan et al. (2010) noted that the strength of the shell depends on the thickness of the palisade layer and the organization of calcite crystals in this layer. Solomon (1991) suggested that the organization of the columns of the palisade layer is one of the major determinants of the rigidity of the shell and therefore the strength, and shell resistance of the eggs. Fathi et al. (2007) noted that changes in the palisade layer thickness will affect the eggshell resistance, with diets supplemented with $\mathrm{Mn}, \mathrm{Zn}$, and $\mathrm{Cu}$ improving the quality of the eggshell produced, especially when these trace minerals are supplied in the form of protein.

The properties of the eggshell depend on the microstructure and chemical composition, which can vary through the thickness of the shell (Bain et al., 2008). It is thought that the supplementation of NDCP participate in the formation of eggshells by influencing the thickness via their action as enablers of important enzymes, such as carbonic anhydrase (Zamani et al., 2005). Also, suggested that the organization of the palisade columns is a major determinant of shell stiffness and therefore of shell strength. Shell strength is directly related to shell thickness (Khatkar et al., 1997). Therefore, a reduction in the cross-sectional length of these layers may increase eggshell porosity resulting in excess water loss during incubation (Parsons, 1982). With respect to breeder age effect, it could be noticed that all eggshell layer were significantly reduced as the age of breeder was advanced. Increased erosion of the calcium reserve assembly region of the mammillary layer as the breeder hen ages (Nascimento et al., 1992) could potentate separation of the mammillary layer and shell membranes.

As shown in Fig (1), it could be observed that the incidence of alignment was more prevalent in control eggshells compared to treatments, suggesting lower resistance to breakage. Late and large interstitial spaces of the palisade layer indicating decreased resistance to fracture were observed in control eggshells. It could be concluded that the improvement eggshell quality may be caused by supplementation.

Abnormalities and late fusion had a higher incidence in the control compared to the treatments. Also, in the treatments, the inner eggshell surface had more dense mammillary caps and earlier mammillary fusion than in the control (Fig 1). The breadth between the layers of the eggshell and the lack of healing, as well as incomplete calcification and the surface fusion late of the palisade layer cells evidence of the fragility of the eggshell and lack of resistance to breakage.

The extent to which the palisade layer extends down toward the roots of the mammillary layer appears to be an important factor in determining egg shell quality. This indicates, therefore, that thickness alone is not 


\section{El-Sheikh and Abou-Elnaga}

the only factor affecting shell quality but that the density of the palisade layer is also very important (Fig 2 and 3).

Results of Meyer, et al. (1973) indicate a very poor correlation between breaking strength and shell thickness. While none of the breaking strengths in these two groups of eggs overlapped (fed basal diet containing 3.5\% total calcium or two- third of the limestone had replaced by oyster shell) each other, there was overlapping in the shell thickness values between the two groups of eggs. The ratio of strength to shell thickness for the good eggs was 19.58, while the correlation ratio of strength to thickness of the poorer eggs was only 12.8. It appears, therefore, that shell thickness is a relatively poor measure of egg shell quality, since it does not take into consideration the density of the palisade layer in extending down around the mammillary crystals.

Meyer, et al. (1973) postulated that in eggs from hens receiving calcium-deficient diets, the crystalline, mammillary layer of the egg shell which is first laid down may be nearly normal, but the denser and stronger palisade layer may be thinner, due to an exhaustion of available $\mathrm{Ca}^{2+}$ and/ or $\mathrm{CaCO}_{3}$. Because the scanningelectron microscope has been useful in examining eggshell structure (King and Robinson, 1972), it was selected for detecting eggshell structural differences in this study. Measurements of relative thicknesses of the mammillary and palisade layers of the eggs were used as an effort to explain differences between breaking strength scores and shell thickness measurements.

Figures ( 3 and 4 ) showed that each palisade column grows from one mammillary buttons and as the calcification mechanism proceeds adjacent columns fuse, which provides greater resistance of the shell, this findings is in agreement of Solomon, (2010) who reported that the knowledge of the layers that form the eggshell is important because the specific nucleation sites on the outer surface of the outer shell membrane attracts calcium salts and so initiate the formation of the mammillary layer in that region of the oviduct termed the tubular shell gland and may be influenced by the enzymatic activity.

From Fig (4), it could be observed that the scanning electron micrographs revealed that most of the changes responsible for differences in shell breaking strength appear to take place in the palisade layer, while the mammillary layer remains approximately constant. These results appear to confirm the hypothesis that the palisade layer contributes most of the strength to the shell. As the palisade layer decreased in thickness and in concentration, there was a closely predictable decrease in breaking strength of the eggs.

The present study revealed that in the control group there was clutter on the distribution of mammillary buttons on the inner surface of the shell compared to other treatments group (Fig. 1), and this observation was made in the shell that had a higher density of mammillary buttons (Fig 2). This finding is in agreements with results of Van Toledo et al. (1982), who observed that shell with a higher density of mammillary buttons, cracks, and scratches have clutter on their inner surface and these shells were also less resistant. Such evidence supports the notions that not only do the thickness and the percentage of shell influence resistance but also that the palisade layer thickness and the number of mammillary buttons present in the shell influence shell resistance.

The scanning electron micrographs (Figure 4) revealed that as the breaking strength decreased total shell thickness decreased and palsied layer increased (Tables 3, 4, and 5).

Results in Table (3) show the relationship between eggshell thickness, tibia breaking strength and palisade layer percent. It is known that brown eggs had a higher eggshell quality trait compared to white eggs, but concerning breeder flock age effect, it could be observed that the eggshell thickness, shell strength and tibia strength were decreased with advancing breeder flock ages. Our data reveal that eggshell thickness and tibia breaking strength were significantly increased as NDCP supplementation increased and this increased occurs in parallel with the increase in palisade layer percent; this indicates a good correlation between those traits and indicates that NDCP supplementation helps in improving egg shell quality and protecting the eggs and tibia from breaking.

These results are in agreement with those of Curtis et al. (1985) who noted that eggshell thickness was significantly decreased with increasing breeder flock ages and such phenomena basically relied on the increment in egg size is more quickly than the shell weight, and also the increase in egg size is relatively higher than the rate of calcium deposition in the eggshell. 
Likewise, Silversides and Scott (2001) noticed that the brown eggs recorded significantly higher shell thickness compared to the white ones. Also, shell thickness was significantly affected by breeder flock age, whereas the shell thickness decreases with advancing of hen's ages. Such effect was more pronounced for the brown compared to white breeder strain.

Moreover, Roland (1979) reported that the shell quality at the end of the lay season is directly related to shell quality at the beginning of lay, the reduction in eggshell thickness and eggshell breaking strength as the hen ages been associated with an increase in egg size without a concurrent increase in calcium carbonate deposition. Several reasons have been presented to explain this change in shell strength with age. It has been proposed that the amount of calcium absorb, retains and the skeletal $\mathrm{Ca}$ available for shell calcification decrease with age.

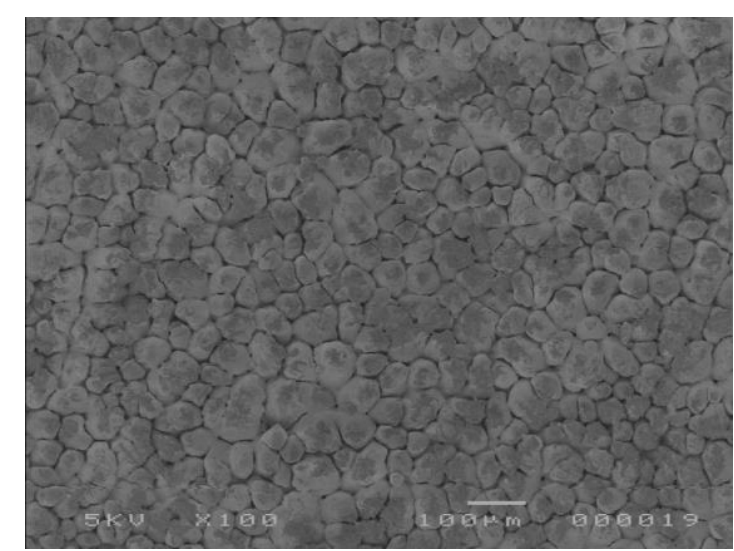

Control

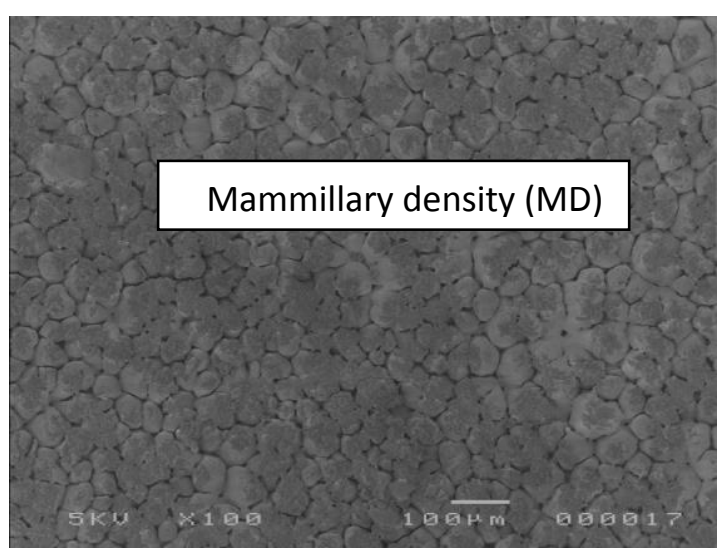

$200 \mathrm{~m} \mathrm{~g} / \mathrm{kg}$

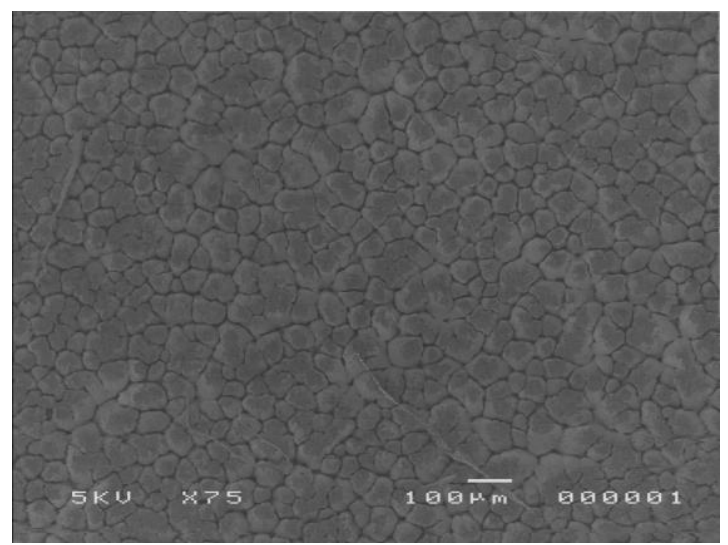

$400 \mathrm{mg} / \mathrm{kg}$

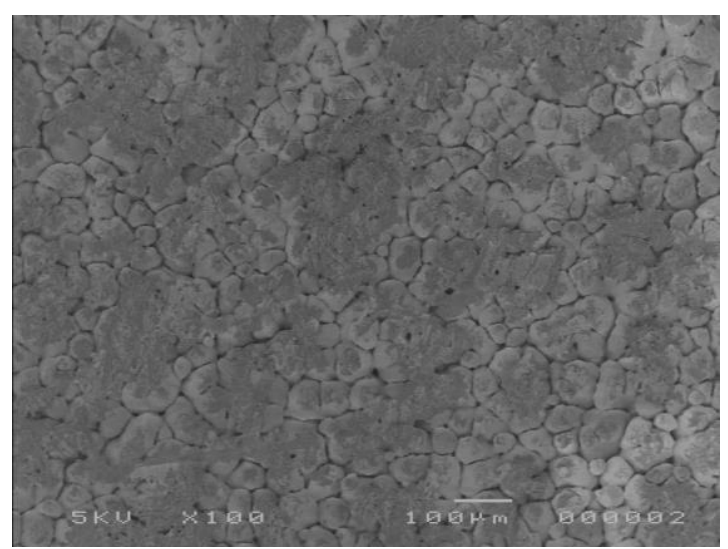

$800 \mathrm{mg} / \mathrm{kg}$

Figure (1): Shows late fusion in eggshell of control and the distances between the palisade layer substrate as well as the degree of incomplete calcification. 

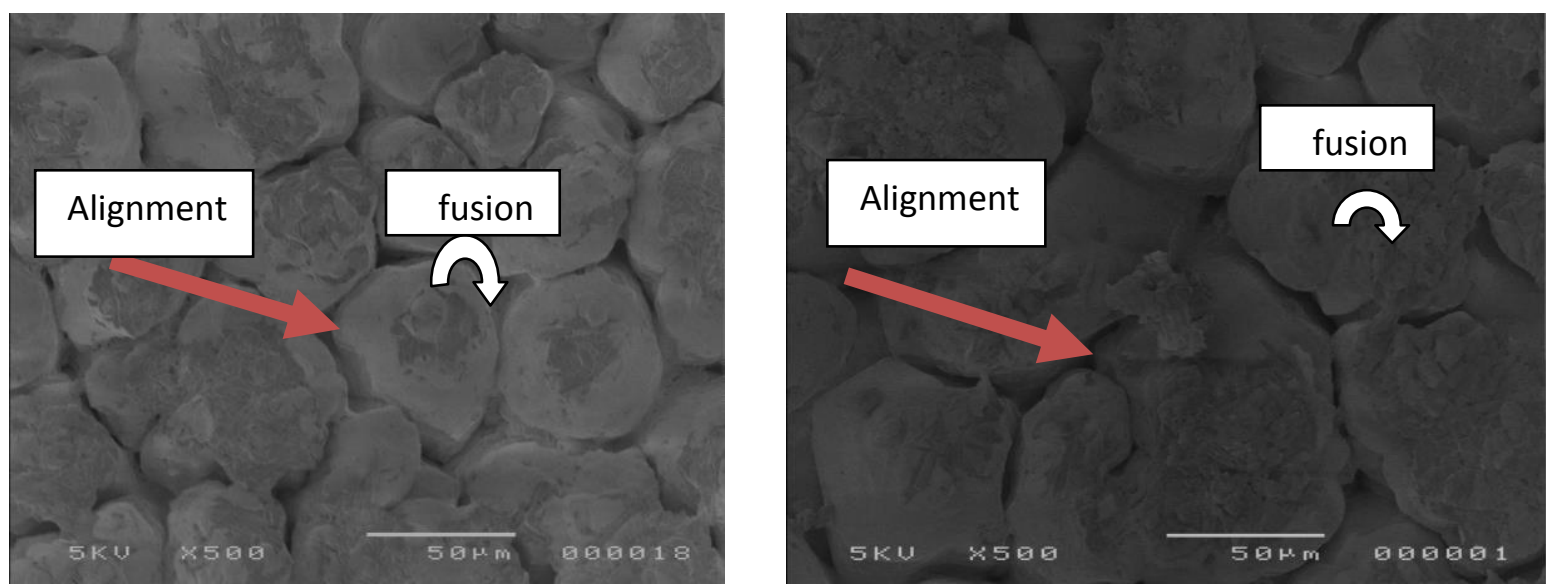

Control

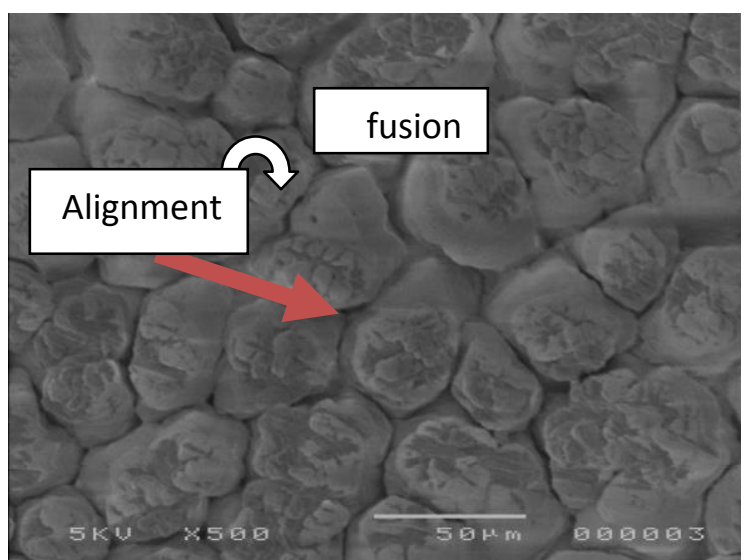

$400 \mathrm{mg} / \mathrm{kg}$

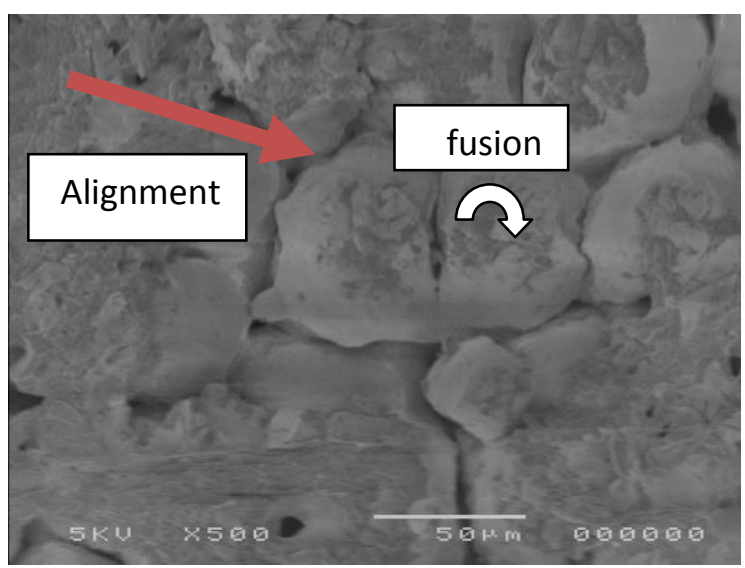

$200 \mathrm{mg} / \mathrm{kg}$

$800 \mathrm{mg} / \mathrm{kg}$

Figure (2): Scanning electron microscopy of the inner surface of the eggshell of laying hens at 62 wk of age. Note the different distribution of mammillary buttons that became larger as levels of supplementation increase in the diet. Density increases as supplemented increase compared to control.
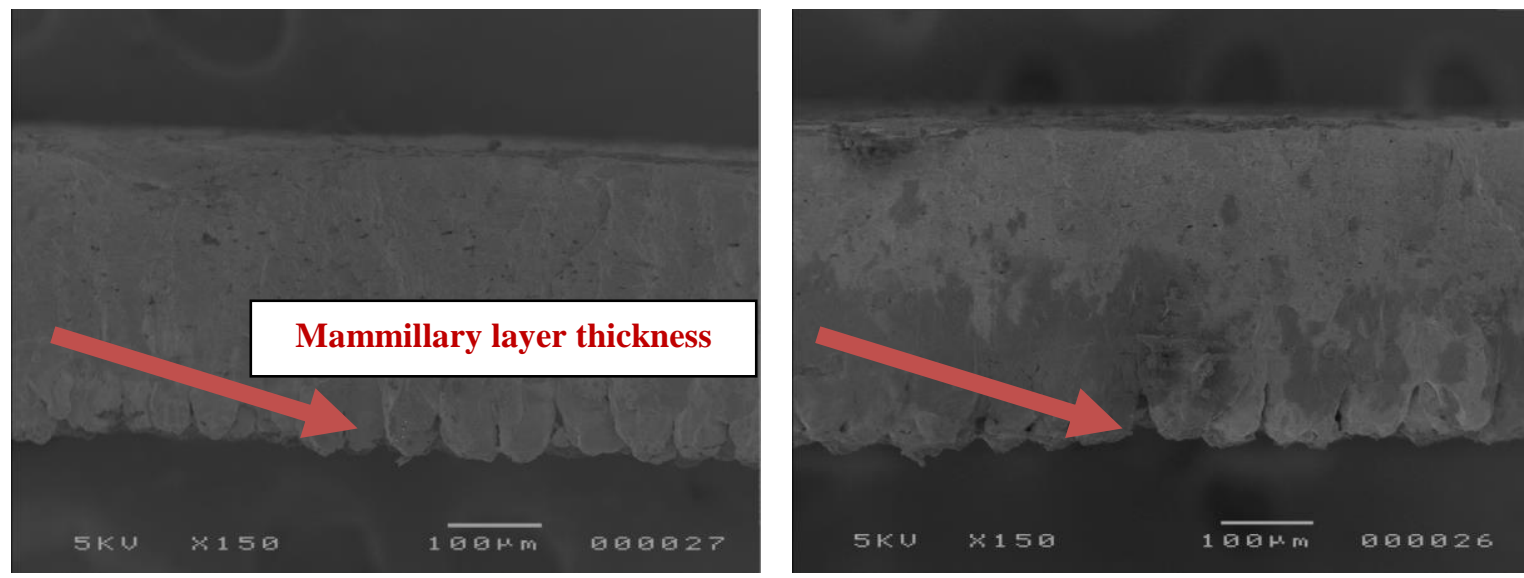

Control

$400 \mathrm{mg} / \mathrm{kg}$ 

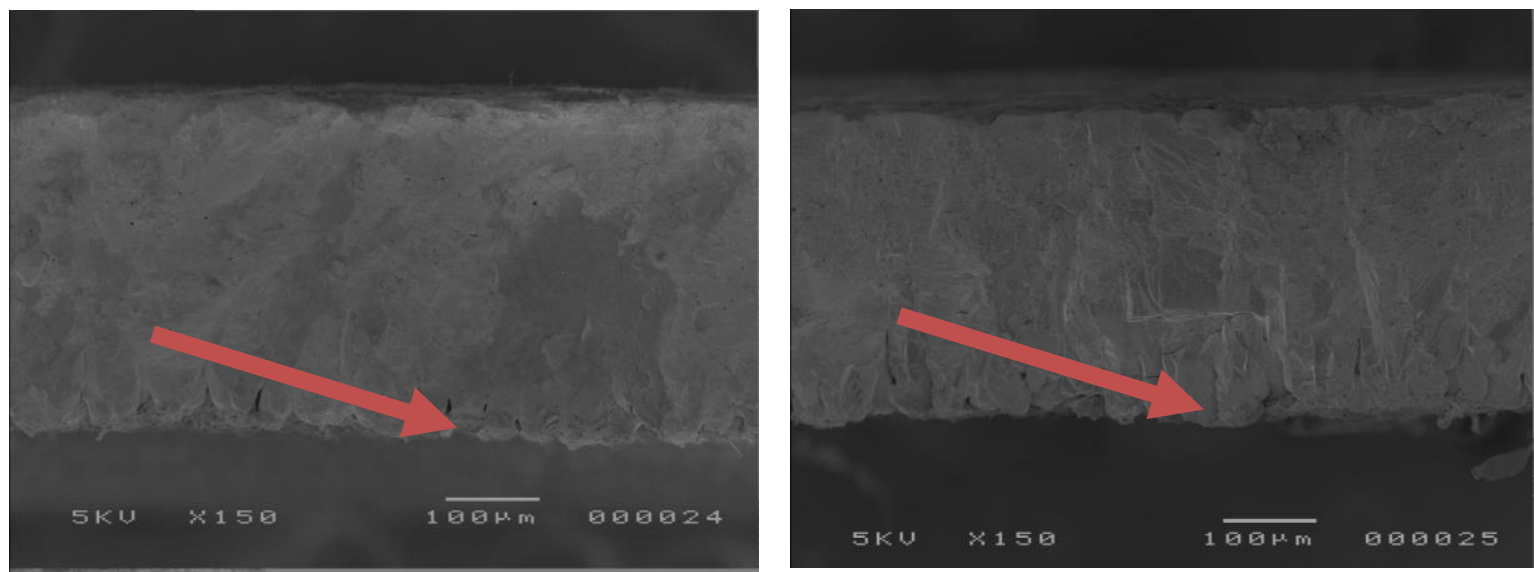

$200 \mathrm{~m} \mathrm{~g} / \mathrm{kg}$

$800 \mathrm{~m} \mathrm{~g} / \mathrm{kg}$

Figure (3): Scanning electron microscopy of the cross section of the eggshell of laying hens at 62 wk of age. Palisade layer (pa), mammillary (ma), and vertical view of the mammillary buttons ( $\mathrm{mb}$ ).
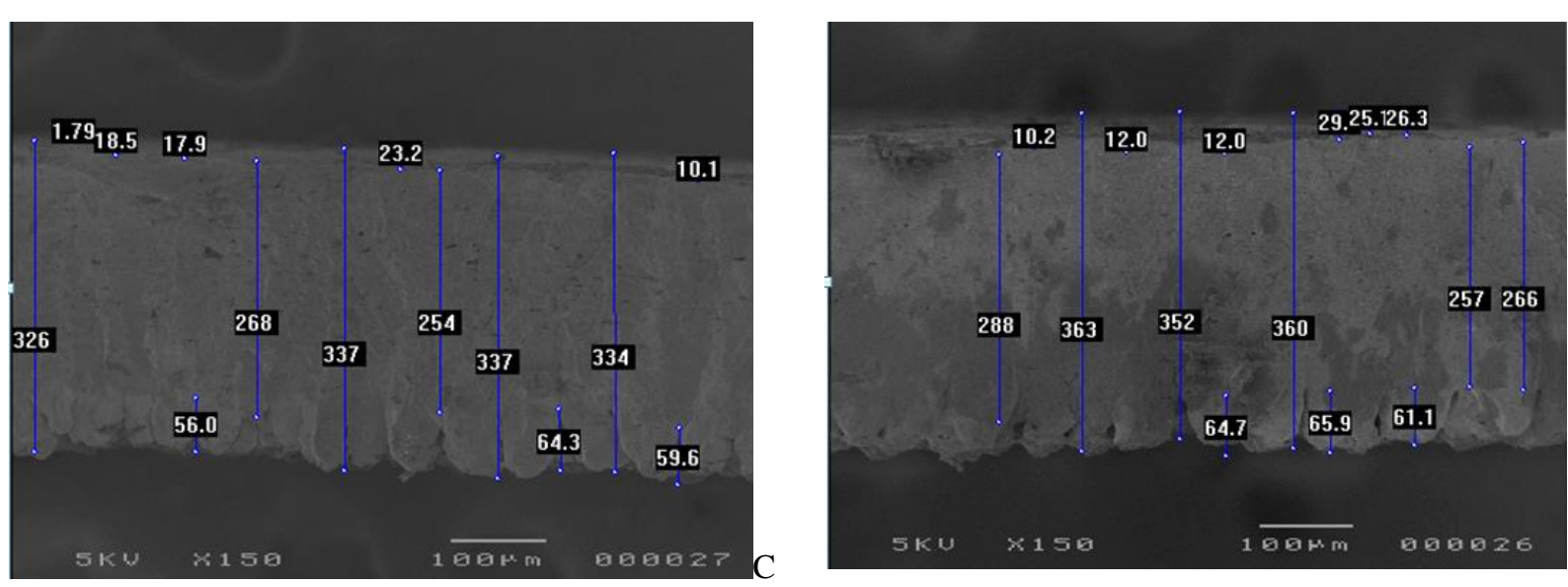

ontrol

$400 \mathrm{mg} / \mathrm{kg}$
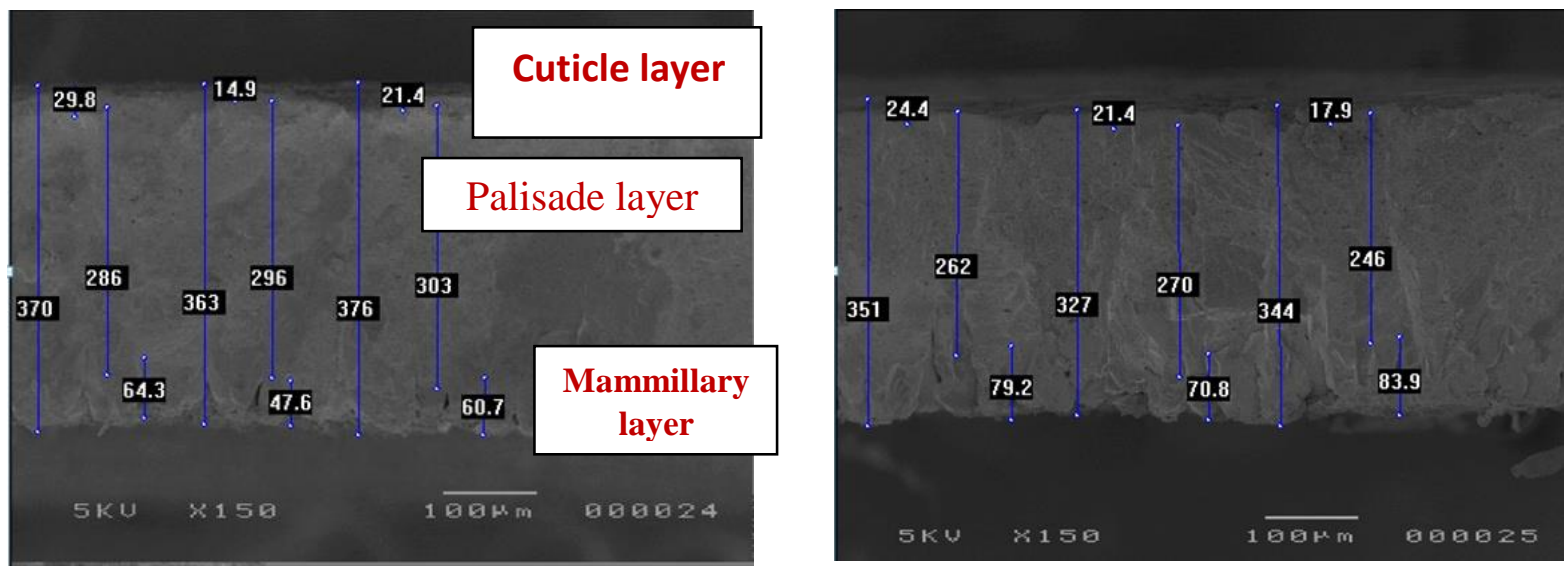

$200 \mathrm{mg} / \mathrm{kg}$

$800 \mathrm{mg} / \mathrm{kg}$

Figure (4): Scanning electron microscopy of the cross section of the eggshell of laying hens at 62 wk of age. Palisade layer (pa), mammillary (ma), and vertical view of the mammillary buttons (mb). 


\section{CONCLUSION}

Supplementation of NDCP affects key performance variables, such as production of eggs, feed intake, and feed conversion. However, supplementation of NDCP did improve quality characteristics and ultrastructure of eggshells. Levels of 200, 400 respectively, resulted in less egg loss and increased strength of egg shell.

\section{REFERENCES}

Allen, L.B., P.H. Sitonen and H.C. Thompson (1997). Methods for the determination of arsenic, cadmium, copper, lead and tin in sucrose, corn syrups and high fructose corn syrups by inductively coupled plasma atomic emission spectrometry. J. Agric. Food Chem., 45 (1):162-165.

AOAC, Association of Official Analytical Chemists (2003). Official Methods of Analysis.Vol.2.Pages 57$58,16^{\text {th }}$ ed., Washington, DC.

Bain, M. M., N. Macleod, R. Thomson and J. W. Hancock (2008). Microcracks in eggs. Poult. Sci. 85:20012008.

Berne, M. R. and M. N. Levy (1998). Fisiologia. 4th ed. Rio de Janeiro: Guanabara Koogan.

Coutts, J. A., G. C. Wilson and S. Fernandez (2007). Optimum Egg Quality. 5M Publishing, Sheffield, UK.

Curtis, P.A., F.A. Gardner and D.B. Mellor (1985). Acomparison of selected quality and compositional characteristics of brown and white eggshells; I. shell quality. Poult. Sci., 64: 297-301.

Duncan, D.B. (1955). Multiple range and multiple F tests.Biometrics. 11:1-42.

Fathi, M. M., A. Zein El-Dein, S. A. El-Safty and L. M. Radwan (2007) . Using scanning electron microscopy to detect the ultrastructural variations in eggshell quality of Fayoumi and Dandarawi chicken breeds. Int. J. Poult. Sci. 6:236-241.

Ganjigohari S., N. Ziaei, A. R. Ghara and S. Tasharrofi (2018). Effects of nanocalcium carbonate on egg production performance and plasma calcium of laying hens. J. Anim. Physiol Anim. Nutr (Berl).102(1):e225-e232.

Gref, R., Y. M. Minamitake, T. Peracchia, V. Trubetskoy, V. Torchilin and R. Langer (1994). Biodegradable long- circulating polymeric nan spheres. Poul.Sci. 263, 1600- 1603.

Gross, K. A., J. Andersons, M.,Misevicius and J. Svirksts (2014). Traversing phase fields towards man-sized beta tricalcium phosphate. Key Engineering Materials, 587:97-100.

Hassan, H.M.A., A. Samy, A.E. El-Sherbiny, M.A. Mohamed and M.O. Abd- Elsamee (2016). Application of Nano- dicalcium Phosphate in Broiler Nutrition: Performance and Excreted Calcium and Phosphorus. Asian Journal of Animal and Veterinary Advances, 11: 477-483.

Hett, A. (2004). Nano technology. Small matter many unknowns. Swiss Reinsurance Company, Zurich.

Jonchere, V. V., A. B. Brionne, J. J. Gautron and Y. Y. Nys (2012). Identification of uterine ion transporters of mineralization precursors of the avian eggshell. BMC Physiol., 10: 12.

Kannaki, T.R. and P.C. Verma (2006).The challenges of 2020 and the role of nanotechnology in poultry research. Proceedings of the National Seminar on Poultry Research Priorities to Centr Avian Res Inst., pp: 273-277.

King, N. R. and D. S. Robinson (1972). The use of the scanning electron microscope for comparing the structure of weak and strong eggshells. J. Microscopy 95:437-443.

Khatkar, M.S., J.S. Sandhu, G.S. Brah and M.L. Chaudhary (1997). Estimation of egg shell breaking strength from egg characteristics in layer chickens.In. J. Poult. Sci., 32: 111-113. 
Lavelin, I., N. Meiri and M. Pines (2000). New insight in eggshell formation. Poul. Sci., 79, 1014- 1017.

Lesson, S. and J. D. Summers (1969). Scott's nutrition of the chicken 4thed. Guelph. Ontario: University Books.

Meyer, R., R. C. Baker and M. L. Scott (1973). Effects of hen egg shell and other calcium sources upon egg shell strength and ultrastructure. Poultry Science, 52(3), 949-955.

Nascimento, V.P., S. Cranstoun and S.E. Solomon (1992). Relationship between shell structure and movement of Salmonella enteritidis across the eggshell wall. Br. Poult. Sci., 33: 37-48.

NRC, National Research Council (1994). Nutrient requirements of poultry. 9th Ed. National Academic Press, Washington. DC.

Nys, Y., J. Gautron, J. M. Garcia-Ruiz and M. T. Hincke (2004). Avian eggshell mineralization: Biochemical and functional characterization of matrix proteins. C. R. Palevol 3:549-562.

Parsons, A.H., (1982). Structure of the eggshell. Poult.Sci., 61: 2013-2021.

Pelicia, K., J. L. Mourao and M. E. A. Garcia (2011). Effects of dietary calcium levels and limestone particle size on the performance, tibia and blood of laying hens. Braz. J. Poul. Sci. 13. 29- 34.

Radwan, L. M., A. Galal, M. M. Fathi and A. Zein El-Dein (2010). Mechanical and ultrastructural properties of eggshell in two Egyptian native breeds of chicken. Int. J. Poult. Sci. 9:77-81.

Rajendran, D., (2013). Application of nano minerals in animal production system. Res. J. Biotec. 8 (3): 1-3.

Roberts, J. R., (2004). Factors affecting egg internal quality and egg shell quality in laying hens. Jpn. Poult. Sci., 41:161-177.

Roland, D.A. Sr., (1979). Factors influencing shell qualityof aging hens. Poult. Sci., 58:774-777.

Sahoo, A., R. K. Swain and S. K. Mishra (2014). Effect of inorganic, organic and nanozink supplemented diets on bioavailability and immunity status of broilers. Innt. J. Adv. Rees., 2: 8228- 837.

Silversides, F.G. and T.A. Scott (2001). Effect of storage and layer age on quality of eggs from two lines of hens. Poult. Sci., 80: 1240-1245.

Sirirat, N., J. J. Lu, A. T. Yu Hang and T. F. Lien (2013). Effect of different levels of nano particles chromium piclonate supplementation on performance, egg quality, mineral retention and tissues mineral accumulation in layer chickens.J. Agric. Sci. Vol.5 No. 2; 2013.

Shirley, R. B. and Jr., H. M. Edwards (2003) .Graded Levels of Phytase Past Industry Standards Improves Broiler Performance. Poul. Sci., 82:671-680.

Solomon, S. E., (1991). Egg and Eggshell Quality. Wolfe, London, UK.

Solomon, S. E., (2010). The eggshell: Strength, structure and function. Brit. Poul. Sci., 51 Suppl 1(sup1):529 .

SPSS. (2011). SPSS 11.0 for Windows. SPSS Inc., Chicago. Standardization administration of china. 2005. National feed Industry Standards for Enzyme Assays in china.

Swain, P.S., D. Rajendran, S. B. Rao and G. Dominic (2015). Preparation and effects of nano mineral particle feeding in livestock; A review. Vet. World, 8: 888-891.

Tiwari, (2015). Effect of calcium phosphate nanoparticles supplementation on mineral utilization and overall performance in commercial broilers. M.Sc. Thesis, Animal Nutrition Department, Faculty of Veterinary and Animal Science, University of Animal and Fishery Science. India.

Van Toledo, B., A. H. Parsons and G. F. Combs (1982). Role of ultrastructure in determining eggshell strength. Poult. Sci. 61:569-572.

Vijayakumar and Balakrishnan (2014). Evaluating the bioavailability of calcium phosphate nano particles as mineral supplement in broiler chicken. Indian J. Sci. Tech. Vol 7(10), 1475- 1480.

Vijayakumar and Balakrishnan (2015). Assessment of calcium phosphate nanoparticles as safe mineral supplement for broiler broiler chicken J. Sci. Tech. Vol. 8(7), 608- 613. 
Williams, B., D. Waddington, S. Solomon, B. Thorp and C. Farquharson (2000). Skeletal development in the meat-type chicken. Br. Poult. Sci. 41:141-149.

Wistedt, A., (2013). Shell Formation and Bone Strength in Laying Hens. Ph. D. Thesis Swedish University of Agricultural Sciences Uppsala 2013.

Zamani, A., H. R. Rahmani, and J. Pourreza (2005). Supplementation of a corn-soybean meal diet with manganese and zinc improves eggshell quality in laying hens. Pak. J. Biol. Sci. 8:1311-1317.

تأثير اضافة نانو ثنائى فوسفات الكالسيوم على تركيب قثرة البيضة ومدى الإستفادة من الكالسيوم والفوسفور

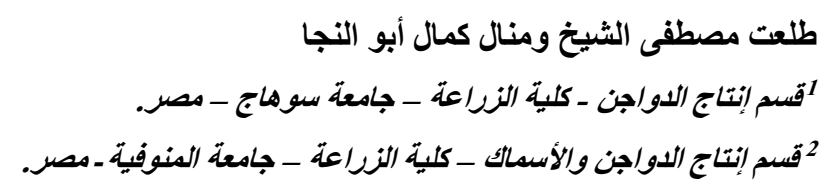

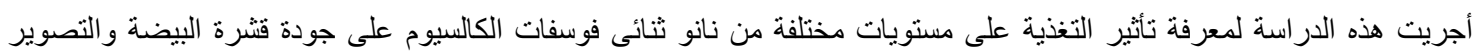

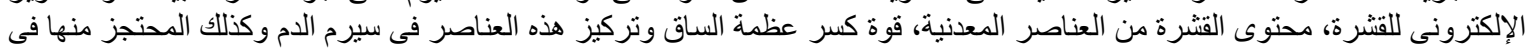

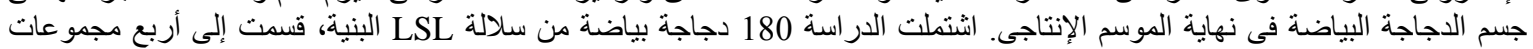

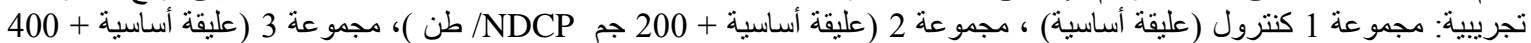

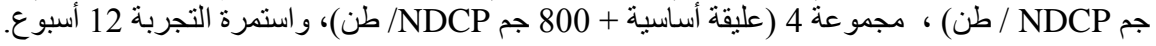

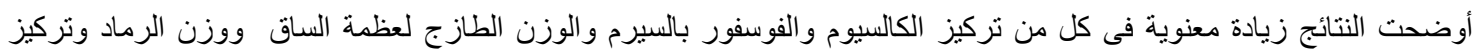

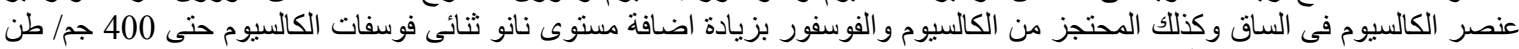

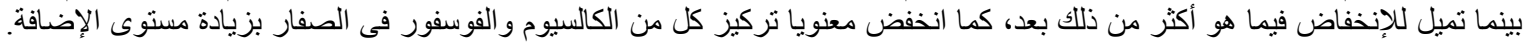

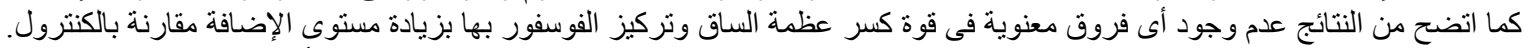

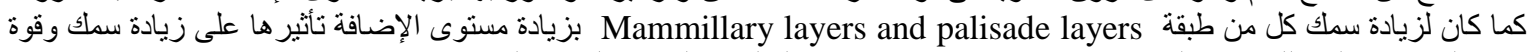

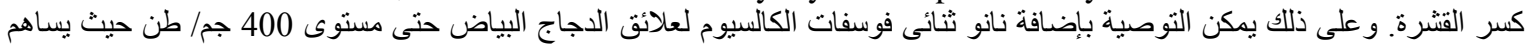
ذللك فى حل مشاكل فشرة البيضة فى نهاية الموسم الإنتاجى. 